\title{
Peer-Assisted Learning: A New Look at the Good Old Monitoring and Its Motivation from the Perspective of Student-Monitor
}

Fernando Henrique Dias Morais ${ }^{1}$, Júlio César André ${ }^{2}$,Emerson Roberto dos Santos ${ }^{3}$, Thaís Santana Gastardelo Bizotto ${ }^{4}$ Sérgio Luís Aparecido Brienze ${ }^{5}$, Alba Regina de Abreu Lima ${ }^{6} \&$ Patrícia da Silva Fucuta $^{7}$

${ }^{1}$ Undergraduate Student in Medicine, Medical School of Medicine of São José do Rio Preto - FAMERP, Brazil. ORCID iD: https://orcid.org/0000-0002-7304-582X

${ }^{2}$ Center for the Study and Development of Health Education - CEDES, Medical School of Medicine of São José do Rio Preto - FAMERP, Brazil - ORCID iD: https://orcid.org/0000-0002-0549-4527

${ }^{3}$ Postgraduate Student in Posgraduation Program in Nursing, Medical School of Medicine of São José do Rio Preto FAMERP, Brazil. ORCID iD: https://orcid.org/0000-0002-9513-1083

${ }^{4}$ Medical School of Medicine of São José do Rio Preto - FAMERP, Brazil. ORCID iD: https://orcid.org/0000-0002-0627-8631

${ }^{5}$ Center for the Study and Development of Health Education - CEDES, Medical School of Medicine of São José do Rio Preto - FAMERP, Brazil. ORCID iD: https://orcid.org/0000-0003-4765-2340

${ }^{6}$ Center for the Study and Development of Health Education - CEDES, Medical School of Medicine of São José do Rio Preto - FAMERP, Brazil. ORCID iD: https://orcid.org/0000-0003-4332-4059

${ }^{7}$ Gastro-Hepatology Service at Hospital de Base of São José do Rio Preto - HB/FUNFARME, Brazil - ORCID iD: https://orcid.org/0000-0002-8342-4970

Correspondence: Júlio César André, Center for the Study and Development of Health Education - CEDES, Medical School of Medicine of São José do Rio Preto - FAMERP, Brazil. ORCID iD: https://orcid.org/0000-0002-0549-4527

Received: December 3, 2019

doi:10.11114/jets.v8i4.4719
Accepted: February 5, $2020 \quad$ Online Published: February 12, 2020

URL: https://doi.org/10.11114/jets.v8i4.4719

\begin{abstract}
Peer-assisted learning (PAL), good old monitoring, has been used in medical schools and shown good results in professional development and in developing communication skills among students. This method provides mutual benefits for both monitors/near-peer teachers - NPT and monitored students; however, little is still known about the NPT' perception about peer-assisted learning. To evaluate the real motivation of students to become NPT, and to investigate how NPT qualify their own teaching activities - such as productivity, performance and difficulties faced seems to be a crucial step for implementing PAL in medical schools. The research instrument, a semi-structured questionnaire with 11 closed questions and 3 questions that allowed the answer "other" and further explanation, was answered by 26 medical students, NPT of basic disciplines. The results showed a positive effect of PAL on the teaching-learning process, and the real reasons of students to become NPT and the positive impacts of PAL on their academic life. The identification of these potential benefits should encourage medical schools to promote training so students can perform their role as NPT since PAL aids in the development of their clinical and pedagogical skills.
\end{abstract}

Keywords: higher education, monitoring, peer-assisted learning, near-peer teachers, medical education

\section{Introduction}

Profound changes have occurred in education in recent decades, most notably in higher education, due to social cultural and technological transformations. Thus, teachers must play the role of facilitator in the acquisition of knowledge by students, and higher education institutions must implement and renew their curricula in the teaching-learning process.

Several active methodologies have been used in medical schools in the current education-learning system (Lincoln \& McAllister, 1993; Silbert et al., 2013), and peer-assisted learning (PAL) is among them, that is, good old monitoring, which has shown good results in professional development and communication skills among students (Tai et al., 2017).

PAL has become part of many medical school curricula (Ross \& Cameron, 2007), predominantly in problem-based 
learning activities (PBL), in which students work together to accomplish the proposed objectives in response to a clinical case (Kassab et al., 2005; Wun, 2007; Ten Cate, 2007). In PAL, students of more advanced grades of the course take on the role of facilitators, tutors or monitors of students of earlier grades, assisting them in the development of academic activities; while teaching, the monitor also learns (Haag et al., 2008). In the interaction between the parties involved, doubts are raised and debated by exchanging experiences and knowledge, allowing hypotheses to be raised and conclusions to be reached. In this dialogue, students actively participate in the knowledge construction, overcoming the authoritarianism of classical education and developing critical sense (Silva et al., 2012). Monitors and their students develop a culture of shared responsibility, helping one another in the teaching-learning process (Topping, 1996; Bulte et al., 2007; Herrmann-Werner et al., 2017; Thampy \& Kersey, 2017).

Innovations in peer-assisted learning have led to its use not only in the teaching of basic sciences but also in the clinical environment (Hamso et al., 2012). In preclinical medicine, PAL was established in the disciplines of anatomy (Rengier et al., 2010; Durán et al., 2012) and physiology (Kibble, 2009; Jackson \& Evans, 2012). In clinical medicine, this method is applied to clinical skills, physical examinations (Field et al., 2007; Silbert et al., 2012; Blank et al., 2013) and surgical procedures (Knobe et al., 2010; Kühl et al., 2012; Tolsgaard et al., 2007). Regardless of the applied area, PAL should never replace the role of a teacher but only constitute an additional instrument to meet the needs in the teaching-learning process (Herrmann-Werner et al., 2017).

\subsection{Historical Context in Brazil}

PAL was introduced in Brazil by the imperial government in 1823 as a way of remedying deficiencies in the educational system, which, at the time, had no trained teachers and financial resources (Topping, 1996). In 1968, the year of creation of the Brazilian Federal University System, Federal Law No. 5,540 was created, adopting academic monitoring (peer-assisted learning) to support educational innovations within universities (Brasil, 1968; Natário, 2001).

The Faculdade de Medicina de São José do Rio Preto (FAMERP), located in the countryside of the state of São Paulo, Brazil, instituted PAL in 1981, under ordinance FUNFARME No. 67, so medical students could assist in the development of the disciplines of Histology and Anatomy. Since then, new monitoring spots were opened for other disciplines of FAMERP's medical course due to the need for improvement in monitoring itself and assistance to responsible teachers.

In 1996, the Brazilian government revoked Law No. 5,540, establishing the Lei das Diretrizes e Bases da Educação Nacional (LDB - Brazilian National Education Guidelines and Framework Law), which describes the monitoring as follows: "Higher education students can be used in teaching and research tasks by their institutions, performing monitoring functions according to their academic results and study plan" (Art. 84) (Brasil, 1996).

Recently, in 2002, due to the needs of renewal and implementation of the medical education curriculum, FAMERP approved the "New Regulatory Standards for Teaching Monitoring in Undergraduate courses" (ordinance FAMERP No. 10), aiming at the following goals: "I. to awaken students' interest in the teaching career; II. to encourage the cooperation of students in undergraduate teaching activities; and III. to provide better conditions of integration of the student in the Institution." Since then, FAMERP monitors must: "I. to collaborate with teachers in performing teaching tasks, preparing practical classes and school work; II. to assist students in performing practical or experimental works, which are always compatible with their degree of knowledge and experience; and III. to cooperate in assisting and guiding students, aiming at greater integration in the School."

\subsection{Related Literature}

The PAL method is mutually beneficial for both monitors and monitored students (Goldschmid \& Goldschmid, 1976; Wagner, 1982; Annis, 1983; Topping \& Ehly, 1998; Ross \& Cameron, 2007; Bugaj et al., 2019). Since monitors and students participate in the same social groups, they are presumed to be "socially congruent" (Morris \& Turmbull, 2004; Bugaj et al., 2019). Consequently, students feel more comfortable with monitors than with teachers (Trevino \& Eiland, 1980; Ebert, 1999; Haag et al., 2008; Dantas, 2014; Loda et al., 2019), that is, they share interpersonal qualities that facilitate informal and empathic communication (Bugaj et al., 2019). Social congruence allows monitors to be more supportive of the needs, difficulties and expectations of students (Franco, 1998; Haag et al., 2008; Dantas, 2014; Loda et al., 2019). Some studies have shown that social and cognitive factors between monitors and students are crucial for aspects such as self-confidence, autonomy, clinical reasoning, self-assessment and peer collaboration (Damon \& Phelps, 1989; Maheady, 1998; Solomon \& Crowe, 2001; General Medical Council, 2003; Bugaj et al., 2019).

Students are often anxious and distressed about the need to learn and achieve satisfactory performance in tests (Goleman, 2011). Knowing that anxiety is deleterious to the acquisition of new information and/or skills, students are reassured by monitors in a context of friendship, being much more affective and relaxed than in formal classes (Dantas, 2014). Several studies have stated that social congruence can also be reflected by monitors encouraging their students to 
actively participate in the class, give feedback, take risks, and ask questions (Masetto, 1975; Escovitz, 1990; Goldsmith, 2006; Loda et al., 2019). Monitoring thus enables the teaching methodology to be adapted according to the students' needs, allowing doubts to be flexibly and spontaneously remedied, and it is up to the monitor to explore the different options of verbal and visual communication available (Topping, 1996), in addition to communicating informally.

On the other hand, monitors also benefit from these methods and can improve their individual knowledge, skills and attitudes while practicing leadership skills (Bugaj et al., 2019). By taking on the responsibility to teach, monitors become closer to the teacher responsible for the discipline to perform tasks within their capabilities such as class preparation, guidance of students and monitoring of the evaluation process, providing the monitor with a greater correlation between theory and practice, and with a multidisciplinary vision.

The monitor also develops skills of communication and speaking, teamwork and leadership, and experiences the teaching activity, getting to know the difficulties and rewards of university teachers. The monitor is inquired by students regarding doubts, school work, information sources, and study materials, revealing personal and pedagogical difficulties for both (Natário, 2001). Monitors thus prepare activities with greater probability of meeting the needs of students (Wagner, 1982; Damon \& Phelps, 1989). The lack of knowledge and experience of the monitors can be compensated by cognitive congruence with the monitored students (Whitman \& Fife, 1988; Weidner \& Popp, 2007; Bugaj et al., 2019).

Monitors may or may not be financially rewarded; however, they report intrinsic rewards such as deeper knowledge acquisition and obtaining of practical skills (Topping, 1996). This can enable monitors to become better apprentices during the undergraduate course and, consequently, during medical residency (Annis, 1983; Bugaj et al., 2019). Currently, the monitoring practice is scored in the entrance exams for medical residency in the main medical schools of Brazil and other countries. The Utrecht Medical School presents a mandatory program in which all students need to act as monitors to complete their training course (Trevino \& Eiland, 1980; Herrmann-Werner et al., 2017).

PAL is also a tool for students seeking to experience the role of university teacher (Sobral, 2002). However, there are rules for those who aspire the early practice of teaching as students (Masetto, 1975; Dantas, 2014). Students must undergo a specific test that evaluates their development capabilities to become monitors (Haag et al., 2008). Thus, PAL is a method that combines the intrinsic interests of the institution that believes in this self-construction instrument, so its students are trained to act professionally and take on their social responsibility with authority (Trevino \& Eiland, 1980; Ebert, 1999).

Despite its benefits (Boud et al., 2001), PAL still has some negative aspects. One is that peer-assisted learning is not yet widely accepted among some students due to some prejudices in having colleagues solve their doubts (Secomb, 2008). Therefore, peer-assisted learning requires a more comprehensive dissemination of its various benefits, which, most of the time, comprises demands and languages that are proper to a given group. Given this scenario, improvements are needed to accomplish and improve this methodology.

Peer-assisted learning has provided various teaching-learning activities, and its benefits can encourage medical schools to develop its implementation (Herrmann-Werner et al., 2017). Identifying difficulties in the implementation of PAL can contribute to improving its use. Learning about good educational practices and practicing them with undergraduate students can lead to better involvement and thus effectiveness in methodological application (Damon \& Phelps, 1989).

The student-monitor's perception of peer-assisted learning can be better known. In this context, our work aimed to answer the following questions: motivations to become a student-monitor, activities developed during the period in which was a student-monitor, reasons for searching the monitoring shift, impact of the monitoring program on the academic life of the student-monitor and the interest in the teaching career, skills developed with the monitoring activity, self-assessment of performance as a student-monitor, self-assessment of the effectiveness of peer-assisted learning (monitoring).

\section{Method}

\subsection{Study Classification and Participants}

This is a cross-sectional descriptive study conducted with students from the Medical course of Faculdade de Medicina de São José do Rio Preto (FAMERP), who were student-monitors in the disciplines of Cell Biology and Histology, from 2013 to 2017, with 26 students in total. This study was approved by the Research Ethics Committee, CAAE: 44661015.8.0000.5415.

\subsection{Data Collection Strategies}

A semi-structured questionnaire, developed by the researchs, with 11 closed questions and 3 questions that allowed respondents to answer as "other" and a small description was used to survey what motives the monitors of these disciplines to seek monitoring, what are the responsibilities of the monitors with the disciplines, the competencies that 
he/she believes to have developed with the monitoring activity, and how important monitoring was in their academic background. The questionnaire was answered after participants read and signed the informed consent form. The results were tabulated and submitted to statistical analysis.

\subsection{Data Analysis}

Exploratory data analysis included the number and proportion for categorical variables. Correlation analysis between ordinal variables was performed by Spearman's correlation coefficient. Statistical analysis was performed using the software IMB-SPSS Statistics version 24 (IBM Corporation, NY, USA). All tests were two-tailed, and significance was considered when $\mathrm{P}<0.05$.

\section{Results}

In total, 26 student-monitors answered the questionnaire and were included in this study. Five of them (19.2\%) had performed more than one monitoring program. Of these student-monitors, four repeated the monitoring program on the same discipline in consecutive years, three of them in Histology and one in Cell Biology. A student-monitor performed 6 monitoring programs for 3 years in a row, alternating between Cell Biology and Histology each semester, consecutively.

Table 1 describes the characteristics related to monitoring and the motivations to be a student-monitor.

Table 1. Characteristics related to monitoring and motivations to become a student-monitor. Categorical variables described in number (percentage)

\begin{tabular}{lc}
\hline Characteristic & $\mathrm{N}=26$ \\
\hline $\begin{array}{l}\text { Number of monitoring programs performed, } \mathrm{n}(\%) \\
\text { One }\end{array}$ & $21(80.8)$ \\
Two & $4(15.4)$ \\
Six & $1(3.8)$ \\
Monitoring discipline, $\mathrm{n}(\%)$ & $14(53.8)$ \\
$\quad$ Histology & $13(50.0)$ \\
Cell Biology & \\
What motivated the participation as a monitors, $\mathrm{n}(\%)$ & $13(50.0)$ \\
$\quad \begin{array}{l}\text { Providing support to the learning of students who present greater degree of difficulty in } \\
\text { the disciplines }\end{array}$ & $8(30.8)$ \\
Obtaining points for residence & $3(11.5)$ \\
Interest in teaching career & $2(7.7)$ \\
$\begin{array}{l}\text { Achieving personal and interpersonal growth } \\
\text { Reviewing the class due to the importance of understanding other disciplines such as } \\
\text { physiology and pathology }\end{array}$ & $1(3.8)$ \\
\hline
\end{tabular}

Regarding the statements about activities developed as a student-monitor, the answers, on a Likert scale, are shown in Table 2 . 
Table 2. Distribution of answers to the statements about activities developed during the period in which the respondent was a student-monitor. Categorical variables described in number (percentage)

\begin{tabular}{lc}
\hline Statement & $\mathrm{N}=26$ \\
\hline "During the monitoring program I had to delve into discipline-related topics", n (\%) & $0(0)$ \\
Completely disagree & $0(0)$ \\
Partially disagree & $1(3.8)$ \\
Indifferent & $13(50.0)$ \\
Partially agree & $12(46.2)$ \\
Completely agree & $0(0)$ \\
"As a student-monitor of the discipline I promoted debates and activities in addition to solving & $0(0)$ \\
questions", n (\%) & $7(26.9)$ \\
Completely disagree & $9(34.6)$ \\
Partially disagree & $10(38.5)$ \\
Indifferent & \\
Partially agree & \\
Completely agree &
\end{tabular}

Regarding the aspects related to the monitored students, three questions addressed this theme. According to the student-monitor's opinion, the main reason monitored students attend the monitoring period is "to get tips about tests". Table 3 lists the reasons and other aspects related to monitored students.

Table 3. Distribution of answers regarding the reasons for searching the monitoring shift, as well as answers to the statements related to the monitored students. Categorical variables described in number (percentage)

\begin{tabular}{lc}
\hline Question / Statement & $\mathrm{N}=26$ \\
\hline "In your opinion what is (are) the main reason(s) why students attend the monitoring period?", n & $17(65.4)$ \\
$\begin{array}{ll}(\%) \\
\text { To get tips about tests }\end{array}$ & $7(26.9)$ \\
To clarify questions & $1(3.8)$ \\
"To strike a good impression" (going to the monitoring so the student can pass on a good & $1(3.8)$ \\
image to the teacher) & $0(0)$ \\
To review topics discussed in class & $0(0)$ \\
"I believe that the performance of monitored students improved during the course", n (\%) & $3(11.5)$ \\
Completely disagree & $15(57.7)$ \\
Partially disagree & $8(30.8)$ \\
Indifferent & \\
Partially agree & \\
Completely agree & $15(57.7)$ \\
"My monitoring shifts were greatly sought after in the disciplines that I monitored", n (\%) & $0(0)$ \\
Completely disagree & $0(0)$ \\
Partially disagree & $4(15.4)$
\end{tabular}


Most participants agreed that the monitoring program positively impacted their academic life. Table 4 lists these details.

Table 4. Distribution of responses related to the impact of the monitoring program on the academic life of the student-monitor. Categorical variables described in number (percentage)

\begin{tabular}{lc}
\hline Statement & $\mathrm{N}=26$ \\
\hline "The monitoring program has aroused my interest in teaching", $\mathrm{n}(\%)$ & $0(0)$ \\
Completely disagree & $0(0)$ \\
Partially disagree & $6(23.1)$ \\
Indifferent & $15(57.7)$ \\
Partially agree & $5(19.2)$ \\
Completely agree & \\
"I intend to continue with monitoring in other disciplines", n (\%) & $0(0)$ \\
Completely disagree & $0(0)$ \\
Partially disagree & $4(15.4)$ \\
Indifferent & $11(42.3)$ \\
Partially agree & $11(42.3)$ \\
Completely agree & \\
"I believe that monitoring was fundamental to my academic life", n (\%) & $0(0)$ \\
Completely disagree & $0(0)$ \\
Partially disagree & $1(3.8)$ \\
Indifferent & $12(46.2)$ \\
Partially agree & $13(50.0)$ \\
Completely agree &
\end{tabular}

The next question analyzed the impact of the monitoring program on the academic life of students whose motivation to participate in it as a student-monitor was the "interest in the teaching career". The results are shown in Table 5.

Table 5. Impact of the monitoring program on the academic life of the student-monitor who sought the monitoring program for the reason "interest in the teaching career". Categorical variables described in number (percentage)

\begin{tabular}{lc}
\hline Statement & $\mathrm{N}=3$ \\
\hline "The monitoring program has aroused my interest in teaching", $\mathrm{n}(\%)$ & $3(100.0)$ \\
$\quad$ Completely agree & \\
"I intend to continue with monitoring in other disciplines", $\mathrm{n}(\%)$ & $3(100.0)$ \\
$\quad$ Completely agree & \\
"I believe that monitoring was fundamental to my academic life", $\mathrm{n}(\%)$ & $1(33.3)$ \\
$\quad$ Partially agree & $2(66.7)$ \\
$\quad$ Completely agree &
\end{tabular}

When asked about the skills developed with the monitoring activity, most responded "public communication skills" (57.7\%). The results are shown in Table 6. 
Table 6. Skills developed with the monitoring activity. Categorical variables described in number (percentage)

\begin{tabular}{lc}
\hline Skill, n (\%) & $\mathrm{N}=26$ \\
\hline Public communication skills & $15(57.7)$ \\
Acquisition of different pedagogical means for knowledge transmission & $6(23.1)$ \\
Improvement in the planning and execution of tasks & $4(15.4)$ \\
Greater theoretical-practical understanding of the discipline & $1(3.8)$ \\
\hline
\end{tabular}

In the self-assessment of their performance as a student-monitor, on a Likert scale, most (65.4\%) referred to their performance as "good". The results are shown in Table 7 and Figure 1.

Table 7. Self-assessment of performance as a student-monitor. Categorical variables described in number (percentage)

\begin{tabular}{lc}
\hline Self-assessment, $\mathrm{n}(\%)$ & $\mathrm{N}=26$ \\
\hline Terrible & $0(0)$ \\
Poor & $0(0)$ \\
Average & $6(23.1)$ \\
Good & $17(65.4)$ \\
Excellent & $3(11.5)$ \\
\hline
\end{tabular}

\section{Self-assessment of performance as a student- monitor}

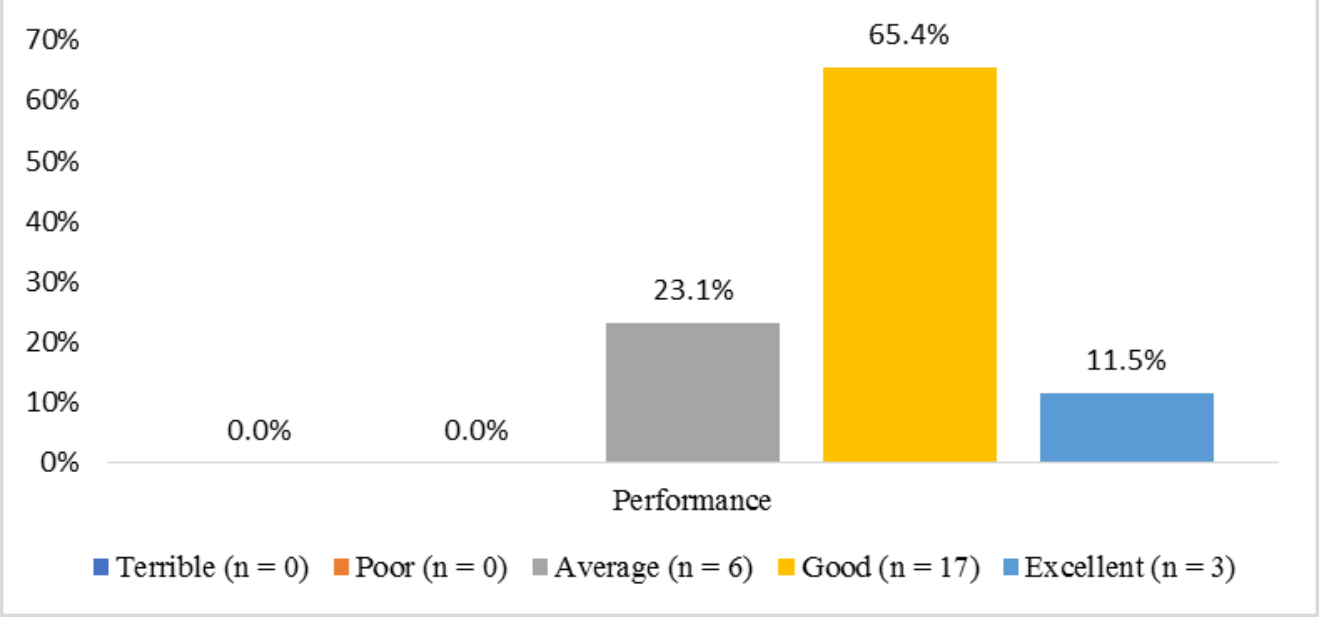

Figure 1. Self-assessment of performance as a student-monitor $(\mathrm{N}=26)$.

The last question referred to the effectiveness, in the opinion of the student-monitor, about peer-assisted learning (monitoring). In total, 24 (92.3\%) participants considered it "good" and "excellent" (Table 8 and Figure 2). 
Table 8. Student-monitor opinion on the effectiveness of peer-assisted learning (monitoring). Categorical variables described in number (percentage)

\begin{tabular}{lc}
\hline Effectiveness of peer-assisted learning, $\mathrm{n}(\%)$ & $\mathrm{N}=26$ \\
\hline Terrible & $0(0)$ \\
Poor & $0(0)$ \\
Average & $2(7.7)$ \\
Good & $18(69.2)$ \\
Excellent & $6(23.1)$ \\
\hline
\end{tabular}

\section{Student-monitor opinion on the effectiveness of peer-assisted learning $(\mathrm{N}=26)$}

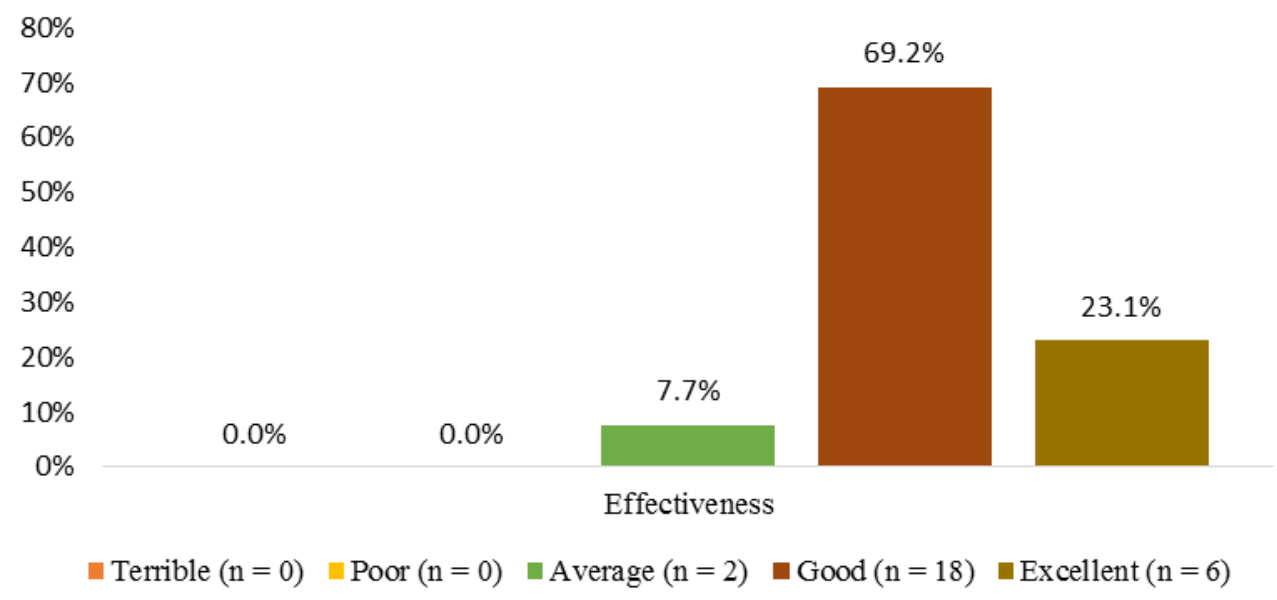

Figure 2. Student-monitor opinion on the effectiveness of peer-assisted learning (monitoring).

In the correlation analysis between self-assessment of performance as a student-monitor and the effectiveness of peer-assisted learning, a moderate positive correlation was observed between the two variables, as shown in Table 9.

Table 9. Correlation analysis between the self-assessment of performance as a student-monitor and effectiveness of peer-assisted learning

\begin{tabular}{lcc}
\hline & $r^{*}$ coefficient & P value \\
\hline $\begin{array}{l}\text { Self-assessment of performance as a } \\
\text { student-monitor and effectiveness of peer-assisted } \\
\text { learning }\end{array}$ & 0.434 & $\mathbf{0 . 0 2 7}$ \\
\hline
\end{tabular}

Spearman's correlation.

On the other hand, there was a slight positive correlation between the performance of monitored students and the self-assessment of performance as a student-monitor $(\mathrm{r}=0.291)$, although without achieving statistical significance $(\mathrm{p}=$ 0.149); however, according to the student-monitor there was no correlation with the effectiveness of peer-assisted learning. The results are shown in Table 10. 
Table 10. Correlation analysis between improvement in the performance of monitored students and self-assessed performance as a student-monitor, and effectiveness of peer-assisted learning

\begin{tabular}{lcc}
\hline & $r^{*}$ coefficient & P value \\
\hline $\begin{array}{l}\text { Improvement in the performance of monitored } \\
\text { students and self-assessed performance as a }\end{array}$ & 0.291 & 0.149 \\
student-monitor & & 0.777 \\
$\begin{array}{l}\text { Improvement in the performance of monitored } \\
\text { students and effectiveness of peer-assisted learning }\end{array}$ & 0.058 & \\
\hline
\end{tabular}

Spearman's correlation.

Table 11 describes the relationship between the initial motivation to participate in the program as a student-monitor and the skills acquired with the development of monitoring activity.

Table 11. Initial motivation to participate as a student-monitor and skills acquired with the monitoring activity descriptive analysis. Variables are described in number

\begin{tabular}{|c|c|c|c|c|c|c|}
\hline & & \multicolumn{5}{|c|}{ Initial motivation to participate in the program as a student-monitor } \\
\hline & & $\begin{array}{l}\text { Obtaining } \\
\text { points for } \\
\text { residence }\end{array}$ & $\begin{array}{l}\text { Providing } \\
\text { support to } \\
\text { the learning } \\
\text { of students } \\
\text { who present } \\
\text { greater } \\
\text { degree of } \\
\text { difficulty in } \\
\text { the } \\
\text { disciplines }\end{array}$ & $\begin{array}{c}\text { Achieving } \\
\text { personal and } \\
\text { interpersonal } \\
\text { growth }\end{array}$ & $\begin{array}{l}\text { Interest } \\
\text { in the } \\
\text { teaching } \\
\text { career }\end{array}$ & $\begin{array}{l}\text { Reviewing the } \\
\text { class due to the } \\
\text { importance of } \\
\text { understanding } \\
\text { other } \\
\text { disciplines } \\
\text { such as } \\
\text { Physiology and } \\
\text { Pathology }\end{array}$ \\
\hline \multirow{4}{*}{$\begin{array}{c}\text { Skills } \\
\text { developed } \\
\text { with the } \\
\text { monitoring } \\
\text { activity }\end{array}$} & $\begin{array}{c}\text { Greater } \\
\text { theoretical/practical } \\
\text { understanding of } \\
\text { the discipline }\end{array}$ & 0 & 0 & 0 & 0 & 1 \\
\hline & $\begin{array}{l}\text { Acquisition of } \\
\text { different } \\
\text { pedagogical means } \\
\text { for knowledge } \\
\text { transmission }\end{array}$ & 0 & 4 & 0 & 2 & 0 \\
\hline & $\begin{array}{l}\text { Improvement in the } \\
\text { planning and } \\
\text { execution of tasks }\end{array}$ & 1 & 2 & 0 & 1 & 0 \\
\hline & $\begin{array}{c}\text { Public } \\
\text { communication } \\
\text { skills }\end{array}$ & 6 & 7 & 2 & 0 & 0 \\
\hline
\end{tabular}

\section{Discussion}

Since the 1990s (Bing-You \& Sproul, 1992) it has been observed that physicians in training internships immediately after medical school (residents) may be responsible for up to one third of the teaching of medical students in a clinical setting, and these numbers have grown rapidly in recent decades (Soriano et al. 2010). In parallel, medical education accreditation bodies worldwide, including in the United States (USA), the United Kingdom, and Canada, have declared the importance of teaching as an essential medical skill in their teaching structures (ACGME 2013; GMC 2015; RCPSC 2015), which probably caused the growth in the number of residency programs as teachers. Monitoring, or peer-assisted learning (PAL), emerges in this context due to offering a valuable opportunity for senior medical students to learn about the fundamentals of pedagogy and gain practical teaching experience before entering the residency program (Feret et al., 2017). Educational literature in higher education shows a term coined to refer to the monitor: near-peer teachers (NPT). The term, as it was coined, describes the proximity of senior peer teachers to junior peer learners in contrast to peer 
teachers who are at the same level of training (Ten Cate \& Durning 2007). We shall use this term in this discussion because we consider it extremely appropriate.

This study shows the perception of NPT in relation to their experiences with PAL. Our results showed that the PAL method had a positive effect on the teaching-learning process among medical students and showed the real reasons why students become NPT. PAL is not only a broad concept in medical education but also offers many benefits with only a few potential disadvantages to justify its existence (Herrmann-Werner et al., 2017). However, PAL will also face new barriers and challenges with current technological and cultural transformations (Herrmann-Werner et al., 2017). Given this discussion, new studies are required so that PAL can continue in the medical curriculum.

Through the research instruments, we sought to identify possible barriers, improvement strategies and stakeholders for the perpetuation of PAL in the basic area of a medical course. Half the students interviewed reported that their main motivation to become NPT was to support the learning of students monitored in the disciplines. These data show that there is a certain degree of affection among students, and that they can assist in the teaching-learning process. The construction of the research instrument by the researchers was carried out, although it appears as a semi-structured questionnaire, in such a way that the questions and possible answers give an almost qualitative aspect to the results and minimizes concerns about reliability or validity because it reflects the Brazilian landscape.

The literature suggests that students are more likely to question and discuss issues with their peers than with their professors (Topping, 2005; Thampy \& Kersey, 2017). The roots of PAL are in social constructivism, conception in which knowledge is actively constructed via peer interactions (Thampy \& Kersey, 2017). However, the second reason of the interviewees to become a NPT was to obtain points for admission into the residency program, given that participation in PAL is scored in the curricular evaluation for it. These data show that some students actually seek monitoring to increase their chances of being admitted in the residency program; however, this is not a demerit in itself, since they still provide assistance to the learning of monitored students.

Almost all NPT reported growth in the knowledge of the subjects of the disciplines (Cell Biology and Histology), and the promotion of debates and activities during meetings with students. Peer discussions help synthesize and consolidate the pre-existing knowledge of NPT and clarify students' doubts in a more affective way (Thampy \& Kersey, 2017). The information exchange process not only assists students but the NPT, with a longer-lasting assimilation of content (Weiss \& Needlman, 1998), given that, by working with students to find answers to their questions, NTP can model their curiosity and self-directed learning (Feret et al., 2017).

Among the monitored students, obtaining test tips and clarifying doubts were the main reasons for students to attend the monitoring sessions, according to NPT themselves. In parallel with the data obtained, NPT reported improvements in student performance, and greater demand for guidance by them. Initially, students hesitate to expose their vulnerabilities and deficiencies to peers (Hulsman et al., 2009). Ensuring a stable group of students and NPT can promote greater confidence and ability of students to expose their doubts and difficulties, engage in the process, and become receptive to feedback, thus becoming beneficial for their performance (Green, 2014; Tai et al., 2017).

Our study showed most NPT positively evaluated the impacts of PAL on their academic life, reflected in the interest in teaching, in the continuation of monitoring in other disciplines, and having a fundamental role in their academic life. Recent studies indicate that the social and cognitive congruence between NPT and their students allows a better interaction and increases the enthusiasm of NPT for teaching, being one of the main reasons for their commitment in the role (Thampy \& Kersey, 2017; Bugaj et a., 2019). Moreover, NPT listed other reasons to participate in PAL such as sharing their knowledge with others while improving their scientific knowledge and teaching skills (Thampy \& Kersey, 2017; Bugaj et al., 2019). The acquisition of teaching skills by NPT - acting as educators - can encourage them to invest in peer learning approaches and develop their own conceptions in proper performance during clinical care (Tai et al., 2017).

Among the skills developed and acquired during PAL, most NPT listed public communication and acquisition of different pedagogical strategies to transfer knowledge. Although the NPT are not trained to play their role as such, they report that practicing PAL assists them both in clinical and pedagogical skills (Thampy \& Kersey, 2017). There is evidence that peer evaluation develops educational skills in NPT, thus improving their performance in student orientation (Domuracki et al., 2015; Tai et al., 2017). The training of NPT on good educational practices and on providing feedback while medical students may lead them to an improved involvement in teaching, thus improving the effectiveness of PAL and reducing their anxiety (Sorinola et al., 2014; Tai et al., 2017; Thampy \& Kersey, 2017).

In the self-evaluation, the NPT reported good performance and good effectiveness between them and the students during the PAL sessions. These data corroborate a recent study showing that social and cognitive congruence have high relevance for NPT (Bugaj et al., 2019). Students and their NPT have social congruence since peer learning environments facilitate personal interactions and stimulate learning (Lockspeiser et al., 2008; Thampy \& Kersey, 2017). 
The data obtained in our study showed a positive Spearman's correlation between the performance of NPT and the effectiveness of teaching when considering the improvement in the performance of students and their NPT. These data strengthen the importance of affection and trust among students in peer-assisted learning. Developing a culture of trust and affection can improve the attitudes of NPT in relation to the low performance of students via constructive feedback, constantly inviting students to discuss and report their opinions, thus reducing the influence of the hierarchy of professors over students (Tai et al., 2017). However, no positive correlation was observed between student performance and effectiveness. These findings may have implications for the development of training for NPT by medical schools, aiming to improve their selection. However, new studies are needed to identify, select and train "ideal" NPT for students (Bugaj et al., 2019).

The evaluations between the initial motivation of NPT and the skills acquired by them showed a greater relationship between supporting student learning and the acquisition of public communication $(n=7)$, and between supporting student learning and obtaining points for residency $(n=6)$. These data show that both the student and the monitor can benefit from the implementation of peer-assisted learning. Ross and Cameron (Ross \& Cameron, 2007) highlight the importance of identifying barriers in the structure of courses and institutions for the implementation of PAL but few studies show this so far in the literature (Tai et al., 2016).

Our study evaluated the motivation, the activities developed, the performance of the monitored students and NPT, the interest in teaching, the acquired competencies, and the effectiveness among the students, and the results presented can contribute to the proposition of several strategies to improve and consolidate PAL. The recognition of issues inherent in medical education - such as the intimate correlation between "promotion of debates and activities" and the "improvement in student performance" - can provide strategies in implementing PAL (Tai et al., 2017). Although PAL has become an effective alternative teaching-learning method, there are many fields of application yet to be investigated. There is also a knowledge gap about how the long-term benefits of PAL (Herrmann-Werner et al., 2017).

The contribution of this study lies in the demonstration that peer-assisted learning provides many teaching and evaluation activities, and it can be successfully adopted in a medical course from the identification of numerous potential benefits reported by NPT; this study could thus encourage medical schools to train NPT and develop the implementation of their role.

Although it can be a powerful tool to favor the teaching-learning process among peers, the meetings for this carry within it a hidden curriculum whose negative implications are unknown. Strategies to harness the positive aspects and mitigate less desirable behaviors and attitudes are important considerations for those implementing near-peer teaching (McKenna \& Williams, 2017), with close monitoring of the teacher being recommended and further studies will be needed to further explore these aspects.

\section{References}

Accreditation Council for Graduate Medical Education (ACGME). (2013). Common Program Requirements. Retrieved from https://www.acgme.org/What-We-Do/Accreditation/Common-Program-Requirements

Annis, L. F. (1983). The processes and effects of peer tutoring. Human Learning: Journal of Practical Research \& Applications, 2(1), 39-47.

Bing-You, R. G., \& Sproul, M. S. (1992). Medical students' perceptions of themselves and residents as teachers. Medical Teacher, 14(2-3), 133-138. https://doi.org/10.3109/01421599209079479

Blank, W. A., Blankenfeld, H, Vogelmann, R., Linde, K., \& Schneider, A. (2013). Can near-peer medical students effectively teach a new curriculum in physical examination? BMC Medical Education, 13, 165. https://doi.org/10.1186/1472-6920-13-165

Boud, D. J., Cohen, R., \& Sampson, J. (2001). Peer learning in higher education: learning from \& with each other (pp. 121-123). London, UK: Psychology Press.

Brasil. (1968). Federal Law No. 5540, November 28, 1968. Sets standards for the organization and functioning of higher education and its articulation with the middle school, and gives other measures. Retrieved from https://www2.camara.leg.br/legin/fed/lei/1960-1969/lei-5540-28-novembro-1968-359201-publicacaooriginal-1-pl. html

Brasil. (1996). Law $n^{\circ}$ 9.394, December 20, 1996. Establishes the guidelines and bases of national education. Retrieved from http://www.planalto.gov.br/ccivil_03/Leis/L9394.htm

Bugaj, T. J., Blohm, M., Schmid, C., Koehl, N., Huber, J., Huhn, D., ... Nikendei, C. (2019). Peer-assisted learning (PAL): skills lab tutors' experiences and motivation. BMC Medical Education, 19(1), 353. https://doi.org/10.1186/s12909-019-1760-2 
Bulte, C., Betts, A., Garner, K., \& Durning, S. (2007). Student teaching: views of student near-peer teachers and learners. Medical Teacher, 29(6), 583-590. https://doi.org/10.1080/01421590701583824

Cate, O. T. (2017). Perspective Paper / Perspektive: Peer teaching: From method to philosophy. Zeitschrift für Evidenz, Fortbildung und Qualität im Gesundheitswesen, 127-128, 85-87. https://doi.org/10.1016/j.zefq.2017.10.005

Damon, W., \& Phelps, E. (1989). Critical distinctions among three approaches to peer education. International Journal of Educational Research, 13(1), 9-19. https://doi.org/10.1016/0883-0355(89)90013-X

Dantas, O. M. (2014). Monitoring: source of knowledge for higher education teaching. Revista Brasileira de Estudos Pedagógicos, 95(241), 567-589. http://dx.doi.org/10.1590/S2176-6681/301611386

Domuracki, K., Wong, A., Olivieri, L., \& Grierson, L. E. M. (2015). The impacts of observing flawed and flawless demonstrations on clinical skill learning. Medical Education, 49(2), 186-192. https://doi.org/10.1111/medu.12631

Durán, C. E. P., Bahena, E. N., Rodríguez, M. de L., Baca, G. J., Uresti, A. S., Elizondo-Omaña, R. E., \& López, S. G. (2012). Near-peer teaching in an anatomy course with a low faculty-to student ratio. Anatomical Sciences Education, 5(3), 171-176. https://doi.org/10.1002/ase.1269

Ebert, M. R., Morgan, P. M., \& Harris, L. B. (1999). A comprehensive student peer-teaching programme. Academic Medicine, 74(5), 583-584. http://dx.doi.org/10.1097/00001888-199905000-00051

Escovitz, E. S. (1990). Using senior students as clinical skills teaching assistants. Academic Medicine, 65(12), 733-734. https://doi.org/10.1097/00001888-199012000-00004

Feret, T., Ranna, J, Schwartzsteina, R. M., \& Goodinga, H. C. (2017). Twelve tips for implementation of "student-as-teacher" $\quad$ programs. $\quad$ Medical $\quad$ Teacher, $39(12), \quad$ 1221-1226. https://doi.org/10.1080/0142159X.2017.1333591

Field, M., Burke, J. M., McAllister, D., \& Lloyd, D. M. (2007). Peer-assisted learning: a novel approach to clinical skills learning for medical students. Medical Education, 41(4), 411-418. https://doi.org/10.1111/j.1365-2929.2007.02713.x

Franco, G. P. (1998). An academic experience as a monitor in morphology: histology and anatomy. Revista Gaúcha de $\begin{array}{llll}\text { Enfermagem, } & \text { 19(1), 66-68. } & \text { Retrieved } & \text { from }\end{array}$ https://seer.ufrgs.br/RevistaGauchadeEnfermagem/article/view/4176/2214

General Medical Council (GMC). (2015). Outcomes for graduates. Retrieved from http://www.gmc-uk.org/education/undergraduate/undergrad_outcomes.asp

General Medical Council. (1993). "Tomorrow's Doctors. Recommendations on Undergraduate Medical Curriculum". London: General Medical Council.

General Medical Council. (2003). Tomorrow's doctors. London, UK: General Medical Council. Retrieved from https://www.educacionmedica.net/pdf/documentos/modelos/tomorrowdoc.pdf

Goldschmid, B., \& Goldschmid, M. L. (1976). Peer teaching in higher education: A review. Higher Education, 5(1), 9-33. https://doi.org/10.1007/BF01677204

Goldsmith, M., Stewart,L., \& Ferguson, L. (2006). Peer learning partnership: An innovative strategy to enhance skill acquisition in nursing students. Nurse Education Today, 26(2), 123-130. https://doi.org/10.1016/j.nedt.2005.08.001

Goleman, D. (2011). Emotional intelligence. Rio de Janeiro, RJ: Ed. Objetiva. Retrieved from https://edisciplinas.usp.br/pluginfile.php/4133507/mod_resource/content/2/Inteligencia-emocional-Daniel-Golema n.pdf

Green, J. A. (2014). The effect of English proficiency and ethnicity on academic performance and progress. Advances in Health Sciences Education, 20(1), 219-228. https://doi.org/10.1007/s10459-014-9523-7

Haag, G. S., Kolling, V., Silva, E., Melo, S.C.B., \& Pinheiro, M. (2008). The contributions of monitoring in the teaching-learning process in nursing. Revista Brasileira Enfermagem, 61(2), 215-202. http://dx.doi.org/10.1590/S0034-71672008000200011

Hamso, M., Ramsdell, A., Balmer, D., \& Boquin, C. (2012). Medical students as teachers at CoSMO, Columbia University's student-run clinic: A pilot study and literature review. Medical Teacher, 34(3), e189-197. https://doi.org/10.3109/0142159X.2012.642832

Herrmann-Werner, A., Gramer, R., Erschens, R., Nikendei, C., Wosnik, A., Griewatz, J., ... Junne, F. (2017). Peer-assisted learning (PAL) in undergraduate medical education: An overview. Zeitschrift fur Evidenz, Fortbildung und Qualitat im Gesundheitswesen, 121, 74-81. https://doi.org/10.1016/j.zefq.2017.01.001 
Hulsman, R. L., Harmsen, A. B., \& Fabriek, M. (2009). Reflective teaching of medical communication skills with DiViDU: Assessing the level of student reflection on recorded consultations with simulated patients. Patient Education and Counseling, 74(2), 142-149. https://doi.org/10.1016/j.pec.2008.10.009

Jackson, T., \& Evans, D. (2012). Can medical students teach? A near-peer-led teaching program for year 1 students. Advances in Physiology Education, 36(3), 192-196. https://doi.org/10.1152/advan.00035.2012

Kassab, S., Abu-Hijleh, M., Al-Shboul, Q., \& Hamdy, H. (2005). Gender related differences in learning in student-led PBL tutorials. Education for Health (Abingdon), 2005, 18(2), 272-282. Retrieved from https://search.proquest.com/openview/e457a690cc5ea4f622a06568db2d3daf/1?pq-origsite=gscholar\&cbl=33821

Kibble, J. D. (2009). A peer-led supplemental tutorial project for medical physiology: implementation in a large class. Advances in Physiology Education, 33(2), 111-114. https://doi.org/10.1152/advan.90212.2008

Knobe, M., Münker, R., Sellei, R. M., Holschen, M., Mooij, S. C., Schmidt-Rohlfing, B., ... Pape H. C. (2010). Peer teaching: a randomised controlled trial using student-teachers to teach musculoskeletal ultrasound. Medical Education, 44(2), 148-145. https://doi.org/10.1111/j.1365-2923.2009.03557.x

Kühl, M., Wagner, R., Bauder, M., Fenik, Y., Riessen, R., Lammerding-Köppel, M., ... Celebi, N. (2012). Student tutors for hands-on training in focused emergency echocardiography-a randomized controlled trial. BMC Medical Education, 12, 101. https://doi.org/10.1186/1472-6920-12-101

Lincoln, M. A., \& McAllister, L. (1993). Peer learning in clinical education. Medical Teacher, 15(1), 17-25. http://dx.doi.org/10.3109/01421599309029007

Lockspeiser, T. M., O’Sullivan, P., Teherani, A., \& Muller, J. (2008). Understanding the experience of being taught by peers: the value of social and cognitive congruence. Advances in Health Sciences Education, 13(3), 361-372. https://doi.org/10.1007/s10459-006-9049-8

Loda, T., Erschens, R., Loenneker, H., Keifenheim, K. E., Nikendei, C., Junne, F., ... Herrmann-Werner, A. (2019). Cognitive and social congruence in peer assisted learning - A scoping review. PLoS One, 14(9), e0222224. https://doi.org/10.1371/journal.pone.0222224.

Maheady, L. (1998). Advantages and disadvantages of peer-assisted learning strategies. in: K. J. Topping, \& S. Ehly (Eds.), Peer Assisted Learning (pp. 22). Mahwah, NJ: Laurence Erlbaum Associates, Inc.

Masetto, M. T. (1975). The teacher-student relationship in the educational proposal of the first cycle of PUC-SP for the areas of human sciences and education (Unpublished master's thesis). Pontifícia Universidade Católica (PUC), São Paulo, Brazil.

McKenna, L., \& Williams, B. (2017). The hidden curriculum in near-peer learning: An exploratory qualitative study. Nurse Education Today, 50, 77-81. http://dx.doi.org/10.1016/j.nedt.2016.12.010

Morris, D., \& Turnbull, P. (2004). Using student nurses as teachers in inquiry-based learning. Journal of Advanced Nursing, 45(2), 136-144. https://doi.org/10.1046/j.1365-2648.2003.02875.x

Natário, E. G. (2001). Program of monitors for the performance in Higher Education - Intervention Proposal (Unpublished master's thesis). Universidade Estadual de Campinas, Campinas, Brazil. Retrieved from http://bdtd.ibict.br/vufind/Record/CAMP_4406f28d563798d0666302b7e5bd7c98

Rengier, F., Rauch, P. J., Partovi S., Kirsch, J., \& Nawrotzki, R. (2010). A three-day anatomy revision course taught by senior peers effectively prepares junior students for their national anatomy exam. Annals of Anatomy, 192(6), 396-399. https://doi.org/10.1016/j.aanat.2010.02.008

Ross, M. T., \& Cameron, H. S. (2007). Peer assisted learning: a planning and implementation framework: AMEE Guide no. 30. Medical Teacher, 29(6), 527-545. http://dx.doi.org/10.1080/01421590701665886

Royal College of Physicians and Surgeons of Canada (RCPSC). (2015). CanMEDS 2015 Physician Competency Framework.

Retrieved from http://canmeds.royalcollege.ca/uploads/en/framework/CanMEDS\%202015\%20Framework_EN_Reduced.pdf

Secomb, J. (2008). A systematic review of peer teaching and learning in clinical education. Journal of Clinical Nursing, 17(6), 703-716. https://doi.org/1010.1111/j.1365-2702.2007.01954.x

Silbert, B. I., \& Lake, F. R. (2012). Peer-assisted learning in teaching clinical examination to junior medical students. Medical Teacher, 34(5), 392-397. https://doi.org/10.3109/0142159X.2012.668240

Silbert, B. I., Lam, S. J. P., Henderson, R. D., \& Lake, F. (2013). Students as teachers. Medical Journal of Australia, 199(3), 164-165. http://dx.doi.org/ 10.5694/mja12.10970 
Silva, M. G. F., Lopes, A. C., \& Santos, L. M. (2012). Monitoring as a teaching-learning process and training future chemistry teachers. Paper presented at the III National Symposium on Science and Technology Education, Ponta Grossa, PR. Retrieved from http://www.sinect.com.br/anais2012/html/artigos/ensino\%20qui/22.pdf

Sobral, D. T. (2002). Cross-year peer tutoring experience in a medical school: conditions and outcomes for student tutors. Medical Education, 36(11), 1064-1070. https://doi.org/10.1046/j.1365-2923.2002.01308.x

Solomon, P., \& Crowe, J. (2001). Perceptions of student peer tutors in a problem-based learning programme. Medical Teacher, 23(2), 181-186. https://doi.org/10.1080/01421590020031101

Soriano, R. P., Blatt, B., Coplit, L., CichoskiKelly, E., Kosowicz, L., Newman, L., ... Greenberg, L. (2010). Teaching medical students how to teach: A National Survey of Students-as-Teachers Programs in U.S. Medical Schools. Academic Medicine, 85(11), 1725-1731. https://doi.org/10.1097/ACM.0b013e3181f53273

Sorinola, O. O., Thistlethwaite, J., Davies, D., \& Peile, E. (2014). Faculty development for educators: A realist evaluation. Advances in Health Sciences Education, 20(2), 385-401. https://doi.org/10.1007/s10459-014-9534-4

Tai, J. H. M., Canny, B. J., Haines, T. P., \& Molloy, E. K. (2017). Implementing Peer Learning in Clinical Education: A Framework to Address Challenges In the "Real World". Teaching and Learning in Medicine, 29(2), 162-172. http://dx.doi.org/10.1080/10401334.2016.1247000

Tai, J., Molloy, E., Haines, T., \& Canny, B. (2016). Same-level peer assisted learning in medical clinical placements: A narrative systematic review. Medical Education, 50(4), 469-484. https://doi.org/10.1111/medu.12898

Ten Cate, O., \& Durning, S. (2007). Dimensions and psychology of peer teaching in medical education. Medical Teacher, 29(6), 546-552. https://doi.org/1010.1080/01421590701583816

Thampy, H., \& Kersey, N. (2017). Peer- assisted learning for foundation doctors. Clinical Teacher, 14(3), 180-183. https://doi.org/10.1111/tct.12586

Tolsgaard, M. G., Gustafsson, A., Rasmussen, M. B., HØiby, P., Müller, C. G., \& Ringsted, C. (2007). Student teachers can be as good as associate professors in teaching clinical skills. Medical Teacher, 29(6), 553-557. https://doi.org/10.1080/01421590701682550

Topping, K. J. (1996). The effectiveness of peer tutoring in further and higher education: A typology and review of the literature. Higher Education, 32(3), 321-345. Retrieved from https://link.springer.com/content/pdf/10.1007\%2FBF00138870.pdf

Topping, K. J. (2005). Trends in peer learning. Educational Psychology, 25(6), 631-645. https://doi.org/10.1080/01443410500345172

Topping, K. J., \& Ehly, S. (1998). Peer Assisted Learning. Mahwah, NJ: Laurence Erlbaum Associates, Inc.

Trevino, P. M., \& Eiland, D. C. (1980). Evaluation of basic science, peer tutorial programme for first- and second-year medical students. Journal of Medical Education, 55(11), 952-953. http://dx.doi.org/10.1097/00001888-198011000-00009

Wagner, L. (1982). Peer Teaching: Historical Perspectives. Westport, CT: Greenwood Press.

Weidner, T. G., \& Popp, J. K. (2007). Peer-assisted learning and orthopaedic evaluation psychomotor skills. Journal of Athletic Training, 42(1), 113-119. $\quad$ Retrieved https://www.ncbi.nlm.nih.gov/pmc/articles/PMC1896071/pdf/11062-6050-42-1-113.pdf

Weiss, V., \& Needlman, R. (1998). To teach is to learn twice. Resident teachers learn more. Archives of Pediatrics \& Adolescent Medicine; 152(2), 190-192. https://doi.org/10.1001/archpedi.152.2.190

Whitman, N. A, \& Fife, J. D. (1988). Peer teaching: to teach is to learn twice. ASHE-ERIC Higher Education Report No 4. Wahsington, DC: Association for the Study of Higher Education. Retrieved from https://files.eric.ed.gov/fulltext/ED305016.pdf

Wun, Y., Tse, E. Y., Lam, T., \& Lam, C. L. (2007). PBL curriculum improves medical students' participation in small-group tutorials. Medical Teacher, 29(6), e198-203. http://dx.doi.org/10.1080/01421590701294349

\section{Copyrights}

Copyright for this article is retained by the author(s), with first publication rights granted to the journal.

This is an open-access article distributed under the terms and conditions of the Creative Commons Attribution license which permits unrestricted use, distribution, and reproduction in any medium, provided the original work is properly cited. 